\title{
DÉPORVIDA: a character strengths positive intervention among young soccer players
}

\author{
David Tomé-Lourido $^{1}$ (1) Elkin Andrés Flórez-Domínguez ${ }^{2} \cdot$ Laura Fraga-García $^{2} \cdot$ Marisa Salanova $^{3} \cdot$ Fabrizio Sors $^{4}$. \\ Mauro Murgia $^{4}$
}

Received: 23 July 2021 / Accepted: 16 October 2021 / Published online: 25 November 2021

(c) The Author(s) 2021

\begin{abstract}
In recent years, various intervention programs have been developed to enhance the quality of life of young athletes. This is particularly important for those who live in residences of professional clubs, far from their families. In this regard, we designed a positive psychology intervention program called "DÉPORVIDA", aimed at enhancing character strengths. To assess the efficacy of this 8-week intervention, we tested 28 young soccer players from a Spanish professional club. The intervention program used a strength-based approach from the values in action (VIA) model, and was conducted by club employees with formal academic education. Data were analysed using a set of $2 \times 2$ (intervention $\times$ time) mixed design ANOVAs. Results revealed different trends for the intervention and the control groups participants for seasonal performance satisfaction and percentage of time feeling happy/unhappy, highlighting consistent changes in the desired direction. Overall, the results indicate that the DÉPORVIDA program is a useful tool to promote positive development in young athletes.
\end{abstract}

Keywords Character strengths $\cdot$ Sport satisfaction $\cdot$ Psychological well-being $\cdot$ Soccer players

\section{Introduction}

Currently in the world of professional soccer, many underage players are incorporated each year into the professional team structures, some even moving from their family environment and entering the club's residences. These migrations are mostly national, but also international, made with the promise of future high salaries and lucrative contracts [1]. Considering the number of annual sports licenses, and the quantity of existing professional players, only a small percentage of these players manage to reach the soccer elite and get a professional contract [2,3]. As a consequence, many players leave sports clubs when they reach adulthood without having completed basic studies and having grown up far from their families [4].

David Tomé-Lourido

david.tome.lourido@udc.es

1 University of A Coruña, A Coruña, Spain

2 Real Club Deportivo de la Coruña, S.A.D., A Coruña, Spain

3 Universitat Jaume I, Castellón de la Plana, Spain

4 Department of Life Sciences, University of Trieste, Trieste, Italy
Given this reality, in recent years, various intervention programs have been proposed in the field of education and sports, with the aim of improving the quality of life of these young players [5-7]. Other interventions focused on increasing sports participation and health status levels of young athletes [8], as well as transmitting values considered socially positive $[9,10]$. These interventions were based on a positive development perspective, providing young people with the opportunity to accumulate optimal experiences through their participation in organized activities [11,12]. This participation allows young players to have a healthy, satisfying and productive life, developing social relations and taking part to cultural activities. The positive psychology perspective emerged in the " $50 \mathrm{~s}$ and ' $60 \mathrm{~s}$ of the twentieth century, allowing the study and dissemination of research related to the positive aspects of the human being. Its influence has been highly relevant in various scientific fields such as education, public health, neuroscience and organizational sciences [13].

Intervention programs based on optimal development and positive experiences are linked to several widely studied phenomena in positive psychology, both at the collective level such as positive institutions [14], and at an individual level such as positive emotions and the flow experiences 
[15], or positive personality traits [16]. Focusing on traits, within positive psychology they are considered as positive psychological characteristics that can predict various forms of well-being and performance [17]. These traits are commonly called "character strengths", conceptualized as positive features reflected in thoughts, feelings and behaviours, which differ in people based on moral and cultural values [18]. Like all personality traits, character strengths are expressed along a continuum, where three zones can be identified [19]: underuse (insufficiently expressed strengths in situations that call for them), overuse (overexpressed strengths relative to the situation), and optimal use (appropriate degree of expression for a given situation).

Within sport, there is little evidence regarding the use of intervention programs based on personal strengths by sport psychologist, but enhancing character strengths could become a fundamental part of the strategies that optimize athletes' performance Brady and Grenville [20]. Athletes should be considered as a unique amalgam of their talents, traits and resources that gives them a competitive advantage in their performance context [21]. According to this perspective, helping athletes to develop their unique and exclusive strengths would allow them, potentially, to develop a solid sports confidence.

Boosting character strengths implies improving other variables that increase psychological adjustment, when individuals are taught to use character strengths within the optimal use zone. Based on results from randomized controlled trials, it has been suggested that character strengths facilitate exceptional performance and predict an increase in well-being, self-regulation and satisfaction with one's own psychological needs for relatedness, competence, and autonomy [22, 23].

Looking at the relationship of character strengths with these variables in greater depth, interventions carried out using character strengths led to improvements in performance satisfaction [24, 25]. Similarly, other studies recently showed how character strengths are tightly related to perceived happiness, well-being, and the absence of ill-being $[26,27]$. This relationship found in many cross-sectional studies turns out to be stable over time [27].

Concerning the association between character strengths and self-regulation, research has shown positive relationships between these two variables in cross-sectional and randomized-control designs [28]. Mindfulness training stands out as a promising method to strengthen this relationship, enhancing character strengths over long periods of time [28, 29]. Finally, regarding basic psychological needs, strengths use provides a key support in the attainment of greater need satisfaction. The need satisfaction has a direct influence on motivation, as the perception of satisfying the needs of competence, autonomy and relatedness generates a state of self-determination [30-32].
In line with previous interventions with young athletes aimed at promoting their positive optimal development, we have designed an intervention program called "DÉPORVIDA". This program specifically aims to discover and enhance character strengths in young soccer players, improving their levels of sports performance satisfaction, well-being, self-regulation, and basic psychological needs. In addition, DÉPORVIDA seeks to overcome the existing research-practice gap within the study and intervention on character strengths, where practice moves faster and faster and it is necessary to empirically study the effectiveness of the interventions [33].

The DÉPORVIDA program is based on the values in action (VIA) model, the most widely used one on character strengths [34]. This model identifies 24 strengths, grouped around 6 virtues, as shown in Table 1. Character strengths are seen to be the psychological ingredients defining the virtues [35]. The validity of the VIA model has been confirmed in numerous investigations [18, 36, 37], across 75 nations [38], including the validation work in a cross-cultural sample of 447,573 participants [17].

Based on previous scientific evidence, as well as on the activities of the DÉPORVIDA program — which are specifically designed to act on the character strengths described in the VIA model-we hypothesized the program to be

Table 1 Character strengths of the peterson and seligman model (2004)

\begin{tabular}{ll}
\hline Virtues & Strengths \\
\hline 1. Wisdom & - Creativity \\
& - Curiosity \\
& - Judgment \\
& - Love of learning \\
& - Perspective \\
2. Courage & - Bravery \\
& - Perseverance \\
& - Honesty \\
3. Humanity & - Zest \\
& - Love \\
4. Justice & - Kindness \\
& - Social intelligence \\
& - Teamwork \\
5. Temperance & - Fairness \\
& - Leadership \\
& - Forgiveness \\
& - Humility \\
6. Transcendence & - Prudence \\
& - Self-regulation \\
& - Appreciation of \\
& beauty and excel- \\
lence \\
\end{tabular}


effective in promoting the desired improvements. In particular, we expect to observe improvements in terms of sport performance satisfaction, well-being, self-regulation and basic psychological needs.

\section{Methods}

\section{Participants}

The sample consisted of 28 players belonging to the base soccer categories of the Real Club Deportivo de La Coruña S.A.D, who came from different geographical locations within Spain. Participants were $85 \%$ of the players who lived in the club's official residence. Their age ranged between 14 and 19 years $(M=16.07 ; \mathrm{SD}=1.63)$. Their competition level was regional and national, and their experience in soccer practice ranged from 8 to 16 years $(M=11.61, \mathrm{SD}=2.08)$.

Participation in the program was voluntary and was proposed to all 33 players who lived in the club's residence. An explanatory video of the program was presented to all players. In this video, they were invited to participate in the DÉPORVIDA program, and to attend a meeting where objectives and activities would be explained. Among all players, 10 agreed to participate to the program, $18 \mathrm{did}$ not agree to participate but accepted to serve as a control group, and the remaining 5 did not participate to the study. All participants involved in the study completed all the assessment phases.

The current Spanish and European regulations regarding data protection were considered at all times. The study followed the recommendations of the Ethics Commission of Research of the University of A Coruña and the Declaration of Helsinki (1964). Informed consent was obtained for each participant; regarding underage players, informed consent was obtained from the parents and the club, considering the overall transfer of rights that they give to the club once the season begins.

\section{Design and measures}

A quasi-experimental study was carried out, as shown in Fig. 1, where the intervention group appears in the first row, while the control group appears in the second row.
The program activities were additional to the normal training schedule of the players, and were carried out in group, for eight consecutive weeks, between February and April 2019. All activities were directed by the club employees with formal academic education (in psychology, pedagogy or sports science); in addition, all of them had a university master's degree in teaching. In each workshop, the different strengths of the VIA model were trained. Activities were not directly related to soccer, but it was used as the basis for the explanation of various principles. The schedule of the activities, their objectives, as well as their relationship with each character strength and dependent variables, can be found in Appendix. These activities were scheduled during participants' free time, not to interfere with the normal daily activities of all players living in the club's residence (i.e., school classes, training and competitions). For this reason, some activities were carried out during the weekends. The activities had a variable duration, depending on their characteristics, ranging between 1 and $3 \mathrm{~h}$.

\section{Independent variables}

The first independent variable was Intervention, with two levels: (1) intervention with the activities of the DÉPORVIDA program (intervention group); (2) no intervention (control group). The second independent variable was Time, with two levels: (1) initial evaluation; (2) final evaluation.

\section{Dependent variables}

The dependent variables measured during the initial and final evaluations were the following ones.

Sport performance satisfaction The Performance Satisfaction Scale was used [39], which evaluates performance satisfaction at the present time, throughout the season, and assessing the entire sports career. The three items can be used individually, or as a factor, since together they have a Cronbach's alpha of 0.74 . Responses are collected on a 5-point Likert scale: $1=$ Very dissatisfied, $2=$ Dissatisfied; $3=$ Neither satisfied nor dissatisfied; $4=$ Satisfied; $5=$ Very satisfied.
Fig. 1 Quasi-experimental design of the intervention

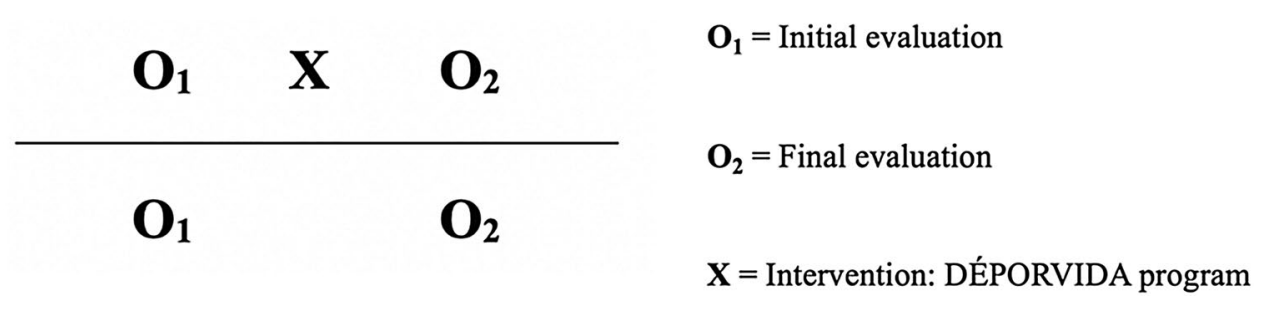




\section{Well-being}

The following scales were used:

a) the Fordyce Questionnaire [40], translated into Spanish and available on the University of Pennsylvania website [41]. This questionnaire presents a test-retest reliability coefficient of 0.86 . Participants indicate the percentage of time in which he/she is happy, neutral and unhappy, totalled up to $100 \%$ between the three. In addition, subjects must evaluate their degree of perceived happiness from 1 to 10 .

b) the Spanish adaptation of Ryff's Psychological Wellbeing Questionnaire was used [42], which presents the following factors: self-acceptance, positive relationships, autonomy, control of the environment, personal growth and purpose in life. The values of Cronbach's alpha in these factors are ranging from 0.70 to 0.84 . Responses are collected on a 6-point Likert scale ranging from 1 (completely disagree) to 6 (completely agree).

\section{Self-regulation}

The factors of Emotional Control and Attention Control of the Spanish Adaptation of the Test of Performance Strategies 3 Competition Subscale were used [43]. These factors are measures of the athletes' capacity for self-regulation (cognitive and emotional) during competition [39]. The first factor had a value of Cronbach's alpha of 0.85 and the second factor of 0.77 . Responses are collected on a 5-point Likert scale: $1=$ Almost never, $2=$ Rarely; $3=$ Sometimes; $4=$ Often; $5=$ Almost always.

\section{Basic psychological needs}

The Spanish adaptation of the Basic Needs Satisfactions in Sport Scale was used [30]. This questionnaire contains the following factors: autonomy-choice, autonomy perceived as internal locus of control, autonomy-will, competence and relatedness. The composite reliability values of these factors ranged from 0.87 to 0.95 . Responses are collected on a 7-point Likert scale ranging from 1 (completely disagree) to 7 (completely agree).

\section{Data analyses}

All analyses were performed using the IBM SPSS Statistics statistical package, version 25.0. The following data analyses were carried out sequentially: first, the descriptive statistics for all dependent variables were calculated. Next, pre-test values of intervention and control groups were compared by means of one-way ANOVAs. Third, mixed design $2 \times 2$ ANOVAs were conducted for each independent variable.
Finally, as follow-up tests for the dependent variables showing a significant interaction, a set of repeated measures and between groups ANOVAs were conducted. For all analyses, the alpha level was set at 0.05 .

\section{Results}

The descriptive statistics of the study variables before and after the program implementation, both for the intervention (INT) and control (CON) groups, are reported in Table 2.

No significant differences were found in any dependent variable at the beginning of the study (i.e., at pre-test). Thus, the two groups were suitable for a quasi-experimental study [44].

A set of mixed design $2 \times 2$ ANOVAs showed significant time $\times$ intervention interactions for the following indicators: seasonal performance satisfaction $[\mathrm{F}(1,26)=9.191$; $\left.p=0.005 ; \eta_{p}{ }^{2}=0.261\right]$; percentage of time experienced as happy $\left[\mathrm{F}(1,26)=8.945 ; p=0.006 ; \eta_{p}{ }^{2}=0.256\right]$; and percentage of time experienced as unhappy $[\mathrm{F}(1,26)=7.682$; $\left.p=0.01 ; \eta_{p}{ }^{2}=0.228\right]$. The three significant interactions consistently showed an effect of the intervention in the desired direction (Fig. 2).

For the variables showing a significant interaction, within groups pre- vs. post-test comparisons were performed. The results revealed that the intervention group, at the end of the intervention, presented an increase in Seasonal performance satisfaction $\left[\mathrm{F}(1,9)=7.364 ; p=0.024 ; \eta_{p}{ }^{2}=0.45\right]$. Instead, the control group presented a decrease in the Percentage of time experienced as happy $[\mathrm{F}(1,17)=10.842$; $\left.p=0.004 ; \eta_{p}{ }^{2}=0.389\right]$ and an increase in the Percentage of time experienced as unhappy $[\mathrm{F}(1,17)=9.154 ; p=0.008$; $\left.\eta_{p}{ }^{2}=0.35\right]$. No significant differences were found for the other comparisons.

Finally, the post-test results for these three variables were compared between the two groups. The results revealed that the intervention group had lower values in Percentage of time experienced as unhappy, compared to the control group $\left[\mathrm{F}(1,26)=4.308 ; p=0.048 ; \eta_{p}{ }^{2}=0.166\right]$. Conversely, no significant differences were found for the seasonal performance satisfaction and the percentage of time experienced as happy.

\section{Discussion}

In the present study, we tested whether an intervention program based on the discovery and development of one's own character strengths, called DÉPORVIDA, entailed higher levels of sports performance satisfaction, well-being, selfregulation, and satisfaction of basic psychological needs. 
Table 2 Descriptive statistics of the dependent variables in the pre-test and post-test

\begin{tabular}{|c|c|c|c|c|c|c|c|c|}
\hline \multirow[t]{3}{*}{ Constructs and indicators } & \multicolumn{4}{|c|}{ Intervention group } & \multicolumn{4}{|c|}{ Control group } \\
\hline & \multicolumn{2}{|c|}{ Pre-test } & \multicolumn{2}{|c|}{ Post-test } & \multicolumn{2}{|c|}{ Pre-test } & \multicolumn{2}{|c|}{ Post-test } \\
\hline & $\mathrm{M}$ & SD & $\mathrm{M}$ & SD & $\mathrm{M}$ & SD & $\mathrm{M}$ & SD \\
\hline Sport performance satisfaction & 3.83 & 0.36 & 4.10 & 0.32 & 3.94 & 0.68 & 3.72 & 0.99 \\
\hline Current PS & 4.00 & 0.47 & 3.80 & 0.63 & 3.78 & 1.06 & 3.50 & 1.43 \\
\hline Seasonal PS & 3.60 & 0.52 & 4.20 & 0.42 & 3.72 & 0.96 & 3.44 & 1.20 \\
\hline Sports career PS & 3.90 & 0.74 & 4.30 & 0.68 & 4.33 & 0.49 & 4.22 & 1.00 \\
\hline Well-being & / & l & I & / & l & I & l & I \\
\hline Perceived happiness & 7.60 & 1.17 & 8.00 & 0.94 & 7.72 & 0.90 & 7.00 & 1.82 \\
\hline$\%$ Happy time & 60.00 & 24.15 & 65.50 & 19.36 & 66.67 & 12.60 & 55.83 & 17.00 \\
\hline \% Unhappy time & 17.50 & 14.77 & 13.50 & 8.18 & 12.78 & 6.91 & 24.44 & 15.42 \\
\hline$\%$ Neutral time & 22.50 & 16.37 & 21.00 & 16.63 & 20.56 & 9.38 & 19.72 & 10.21 \\
\hline Self-acceptance & 4.90 & 0.91 & 4.88 & 0.78 & 5.06 & 0.86 & 4.99 & 0.77 \\
\hline Positive relationships & 4.82 & 1.33 & 4.76 & 0.85 & 4.73 & 1.16 & 4.93 & 1.06 \\
\hline Autonomy & 4.63 & 0.94 & 4.78 & 0.61 & 4.59 & 0.79 & 4.47 & 0.77 \\
\hline Control of the environment & 4.52 & 0.87 & 4.66 & 0.63 & 4.52 & 0.61 & 4.44 & 0.84 \\
\hline Personal growth & 5.18 & 0.60 & 5.05 & 0.71 & 4.69 & 0.93 & 4.99 & 0.72 \\
\hline Purpose in life & 4.86 & 0.42 & 4.74 & 0.56 & 4.66 & 0.78 & 4.81 & 0.76 \\
\hline Self-regulation & / & / & / & / & l & / & / & l \\
\hline Emotional control & 4.08 & 0.54 & 3.90 & 0.94 & 4.11 & 0.62 & 4.15 & 0.80 \\
\hline Attentional control & 4.33 & 0.68 & 4.28 & 0.97 & 4.40 & 0.72 & 4.26 & 0.62 \\
\hline Basic psychological needs & 5.87 & 0.48 & 6.01 & 0.43 & 5.95 & 0.63 & 5.86 & 0.46 \\
\hline Relatedness & 5.94 & 0.53 & 6.18 & 0.48 & 5.84 & 0.85 & 5.91 & 0.72 \\
\hline Autonomy locus of control & 6.27 & 0.56 & 6.53 & 0.39 & 5.78 & 0.99 & 5.78 & 1.00 \\
\hline Autonomy choice & 5.15 & 0.98 & 5.48 & 0.92 & 5.38 & 0.75 & 5.38 & 0.69 \\
\hline Autonomy will & 5.83 & 1.05 & 5.67 & 0.57 & 6.13 & 0.70 & 6.02 & 0.60 \\
\hline Competence & 5.92 & 0.53 & 6.14 & 0.58 & 6.23 & 0.75 & 6.17 & 0.63 \\
\hline
\end{tabular}

Seasonal PS

5

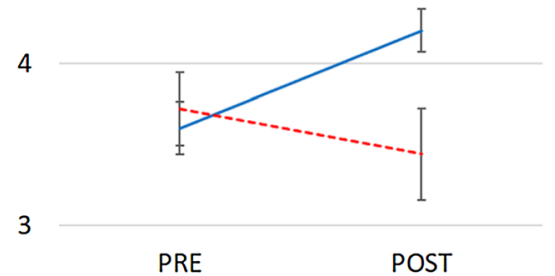

\% Happy time

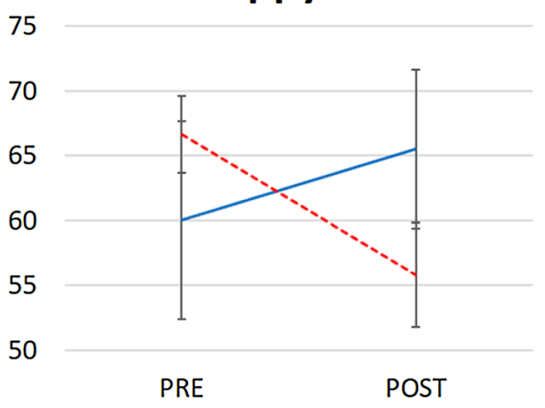

\% Unhappy time

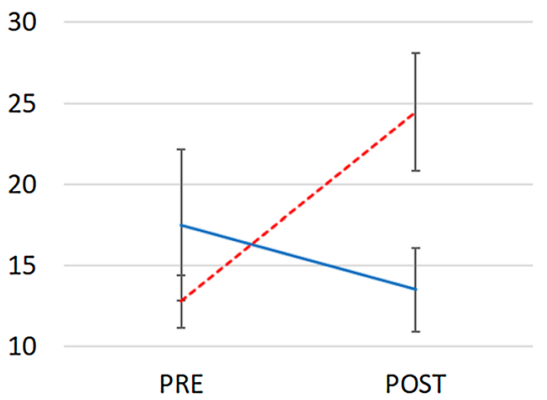

-INT

Fig. 2 Statistically significant interactions. The graphs show the three statistically significant interactions that emerged from the ANOVAs, namely for seasonal performance satisfaction, percentage of

The results provided empirical support to this hypothesis for some of these constructs. In particular, different trends emerged for participants of the intervention and control groups between pre- and post-test for seasonal performance satisfaction and percentage of time feeling happy/unhappy, time experienced as happy, and percentage of time experienced as unhappy. The error bars show the standard error of the mean

highlighting consistent changes in the desired direction. Specifically, the within group comparisons revealed that the seasonal performance satisfaction increased from pre-test to post-test only in the intervention group; instead, in the control group the time experienced as happy decreased and 
that experienced as unhappy increased. Moreover, at posttest, the intervention group participants reported less time experienced as unhappy than the control group.

These results are consistent with previous studies. The relationship between interventions based on positive psychology and performance satisfaction has been established in previous research $[45,51]$. Regarding the relationship between enhancing character strengths and well-being, in terms of percentage of time perceived as happy/unhappy, our results are consistent with previous studies showing that character strengths discovery is strongly linked to happiness indicators [46, 47], as well as other studies related to wellbeing in both general population [48] and adolescents [37]. Recent research shows that strengths-based intervention promotes enhancements in various aspects of well-being [49], both hedonic and eudemonic (positive emotions, engagement, positive relationships, meaning and accomplishment). In fact, psychological well-being and strengths are closely linked to athletic performance [20].

Although the positive relationship between character strengths and some of the basic psychological needs, such as autonomy, has been previously reported [50], no significant differences were found in this study. We cannot exclude that the small sample size of the present study prevented similar effects from being observed. The other dependent variable for which there were no significant results was self-regulation, perhaps due to the choice of inappropriate methods for its measurement. Indeed, the activities of the DÉPORVIDA program were carried out to promote general self-regulation, while the selected instrument evaluates this construct more specifically during sports competitions.

The current study is limited due to its quasi-experimental nature, since there was no randomization when assigning the participants to the groups. Therefore, although the program promoted improvements in the players who participated in it, the results cannot be extended to the population as a whole with the same degree of validity that a purely experimental investigation would have. Future lines of research could focus on improving the allocation of participants to groups, increasing the sample size, and replicating this program in other sports. In addition, future versions of the program should better design the training for self-regulation and select more suitable tools to measure its effects, to appropriately evaluate also this variable.

To conclude, the present study shows that there is favourable evidence regarding the validity of the DÉPORVIDA program to promote the development of character strengths. In line with the other similar programs in the field of education and sport, this program fosters positive development in young athletes. Given that its nature is not directly associated with soccer, DÉPORVIDA could be applied and tested also in other sports.

\section{Appendix}

\section{DÉPORVIDA program activities}

\begin{tabular}{|c|c|c|c|c|c|}
\hline Name & $\begin{array}{l}\text { Intervention day } \\
\text { and duration }\end{array}$ & Objective & Structure & Character strengths & $\begin{array}{l}\text { Dependent vari- } \\
\text { able }\end{array}$ \\
\hline \multicolumn{6}{|l|}{ Week 1} \\
\hline $\begin{array}{l}\text { 1. Program presen- } \\
\text { tation }\end{array}$ & $\begin{array}{l}\text { Intervention } \\
\text { day: } 1 \\
\text { Duration: } 2 \mathrm{~h}\end{array}$ & $\begin{array}{l}\text { Introduce the } \\
\text { concept of } \\
\text { strengths, the } \\
\text { importance of } \\
\text { recognizing } \\
\text { and working } \\
\text { on them }\end{array}$ & $\begin{array}{l}\text { Belén Varela Conference } \\
\text { "Personal strengths in my life". } \\
\text { Expert in organization and } \\
\text { people, she lectures and advises } \\
\text { on talent management }\end{array}$ & $\begin{array}{l}\text { Perspective } \\
\text { Hope } \\
\text { Love of learning } \\
\text { Kindness } \\
\text { Self-regulation }\end{array}$ & $\begin{array}{l}\text { Well-being } \\
\text { Basic psychologi- } \\
\text { cal needs }\end{array}$ \\
\hline 2. Defects & $\begin{array}{l}\text { Intervention } \\
\text { day: } 2 \\
\text { Duration: } 2 \mathrm{~h}\end{array}$ & $\begin{array}{l}\text { Promote a posi- } \\
\text { tive attitude } \\
\text { in program } \\
\text { activities }\end{array}$ & $\begin{array}{l}\text { Record personal defects on } \\
\text { paper } \\
\text { Break the sheet into pieces } \\
\text { Put the pieces together, rein- } \\
\text { force the idea of leaving the } \\
\text { negative aside, and during each } \\
\text { activity, focusing on the positive }\end{array}$ & $\begin{array}{l}\text { Perspective } \\
\text { Hope }\end{array}$ & -Well-being \\
\hline
\end{tabular}




\begin{tabular}{lll}
\hline Name & $\begin{array}{l}\text { Intervention day } \\
\text { and duration }\end{array}$ & Objective \\
\hline 3. Story workshop & $\begin{array}{c}\text { Intervention } \\
\text { day: } 3,4,6\end{array}$ & $\begin{array}{c}\text { Learn to write } \\
\text { stories } \\
\text { Duration: } 1 \mathrm{~h}\end{array}$ \\
& \\
per day &
\end{tabular}

Week 2

4. Emotion work-
shop I
5. Film: "CAMPE-
ONES"

6. Family tree

7. Film:"INSIDE

\section{Week 3}

8. Emotion workshop II

9. VIA Test

Week 4
10. Sharing experi- ences: Aye (club player)

11. Friends tree

12. Training with "Genuine Team"

\section{Week 5}

$\begin{array}{lll}\begin{array}{l}\text { 13. Stories of } \\ \text { strengths }\end{array} & \begin{array}{c}\text { Intervention } \\ \text { day: } 31\end{array} & \begin{array}{c}\text { Be aware of } \\ \text { how they use } \\ \text { their strengths }\end{array} \\ \begin{array}{l}\text { 14. What really } 2 \mathrm{~h} \\ \text { matters }\end{array} & \begin{array}{l}\text { Intervention } \\ \text { day: } 32\end{array} & \begin{array}{c}\text { Reflect on the } \\ \text { things that } \\ \text { really matter }\end{array}\end{array}$

Intervention Literacy in day: $8 \quad$ emotional

- Duration: $2 \mathrm{~h}$ language

- Intervention Reflect on

day: $10 \quad$ values and

- Duration: $2 \mathrm{~h}$ strengths

- Intervention Become aware day: 11 of family and

- Duration: $1 \mathrm{~h}$ roots

- Intervention Deepening the

day: 12 understanding

Duration: $2 \mathrm{~h}$

of emotions

Intervention Literacy in day: 15 emotional

- Duration: $2 \mathrm{~h}$ language

- Intervention Obtain day: 18,19 outstanding

- Duration: $1 \mathrm{~h}$ strengths per day

Intervention Know the life day: 23

Duration: $2 \mathrm{~h}$

of a residence partner, their experiences, strengths and learning

Intervention Be aware of the day: $24 \quad$ close people

- Duration: $1 \mathrm{~h}$ who accompany us

Intervention Become aware day: 25 of the wealth

- Duration: $2 \mathrm{~h}$ that diversity brings

really matter
Structure

Day 3: explanation of structure and examples

- Day 4: creating a story (1)

Choice of characters and their personality

- Day 6: creation of the story Script and writing which they evaluate from 1 to
Explanation of evocation and Self-regulation emotional management concepts Creativity

Movie viewing

Dialogue about observed strengths

- Draw a tree locating parents, grandparents, uncles and cousins

Share the tree with peers

- Movie viewing

- Dialogue about observed emotions

Concept fixation and roleplaying

Day 18: performing VIA test individually

- Day 19: individual interview in 10 how each of them represents them

Guest conference following a Perspective timeline, highlighting important Social intelligence moments in their life and relating it to their strengths

Spirituality

Humor

Gratitude

Kindness

Hope with their experiences

- Draw a tree locating the friends in the roots, trunk or branches

- Share the tree with peers

Joint training with the Club team made up of players with intellectual disabilities and who participate in the Genuine League

Gratitude

Love

Teamwork

Judgment

Social intelligence

Prudence

Honesty

Making stories that show when All each of your personal strengths has been used or has been reflected

Attend the "What really matters" Congress where participants heard inspiring and exemplary life stories
Dependent variable

-Basic psychological needs

-Self-regulation

Well-being

Well-being

Well-being Self-regulation

-Self-regulation

Well-being

Sport performance satisfaction Well-being

Well-being

Basic psychological needs

Sport performance satisfaction

Basic psychological needs

Basic psychological needs 


\begin{tabular}{|c|c|c|c|c|c|c|}
\hline Name & $\begin{array}{l}\text { Intervention day } \\
\text { and duration }\end{array}$ & Objective & Structure & \multicolumn{2}{|c|}{ Character strengths } & $\begin{array}{l}\text { Dependent vari- } \\
\text { able }\end{array}$ \\
\hline $\begin{array}{r}\text { 15. Family } \\
\text { strengths }\end{array}$ & $\begin{array}{l}\text { Intervention } \\
\text { day: } 33 \\
\text { Duration: } 1 \mathrm{~h}\end{array}$ & $\begin{array}{l}\text { Know the } \\
\text { strengths of a } \\
\text { family mem- } \\
\text { ber, relate } \\
\text { them to their } \\
\text { own }\end{array}$ & $\begin{array}{l}\text { VIA test application to a family } \\
\text { member } \\
\text { Group sharing and reflection on } \\
\text { the strengths of their relatives } \\
\text { and their transmission }\end{array}$ & \multicolumn{2}{|l|}{ All } & $\begin{array}{l}\text { Well-being Basic } \\
\text { psychological } \\
\text { needs }\end{array}$ \\
\hline \multicolumn{7}{|l|}{ Week 6} \\
\hline $\begin{array}{l}\text { 16. Sharing } \\
\text { experiences: Juan } \\
\text { Francisco (club } \\
\text { analyst) }\end{array}$ & $\begin{array}{l}\text { Intervention } \\
\text { day: } 38 \\
\text { Duration: } 2 \mathrm{~h}\end{array}$ & $\begin{array}{l}\text { Know his life } \\
\text { in Guatemala, } \\
\text { his sports } \\
\text { retirement, his } \\
\text { experiences, } \\
\text { strengths and } \\
\text { learning }\end{array}$ & $\begin{array}{l}\text { Guest conference following a } \\
\text { timeline, highlighting important } \\
\text { moments in his life and relating } \\
\text { it to their strengths } \\
\text { Questions/debate about their } \\
\text { strengths and the relationship } \\
\text { with their experiences }\end{array}$ & \multicolumn{2}{|l|}{$\begin{array}{l}\text { Perseverance } \\
\text { Love of learning } \\
\text { Bravery } \\
\text { Honesty } \\
\text { Prudence } \\
\text { Kindness }\end{array}$} & $\begin{array}{l}\text { Sport performance } \\
\text { satisfaction } \\
\text { Well-being }\end{array}$ \\
\hline $\begin{array}{l}\text { 17. Sharing experi- } \\
\text { ences: Javi Sandá } \\
\text { (club player) }\end{array}$ & $\begin{array}{l}\text { Intervention } \\
\text { day: } 40 \\
\text { Duration: } 1 \mathrm{~h}\end{array}$ & $\begin{array}{l}\text { Know his } \\
\text { life, his } \\
\text { experiences, } \\
\text { strengths and } \\
\text { learning }\end{array}$ & $\begin{array}{l}\text { Guest conference following a } \\
\text { timeline, highlighting moments, } \\
\text { important aspects of his life and } \\
\text { relating it to his strengths } \\
\text { Questions / debate about their } \\
\text { strengths and the relationship } \\
\text { with their experiences }\end{array}$ & \multicolumn{2}{|l|}{$\begin{array}{l}\text { Perspective } \\
\text { Hope } \\
\text { Kindness } \\
\text { Bravery } \\
\text { Honesty } \\
\text { Zest }\end{array}$} & $\begin{array}{l}\text { Sport performance } \\
\text { satisfaction } \\
\text { Well-being }\end{array}$ \\
\hline $\begin{array}{l}\text { 18. Visit Riazor } \\
\text { stadium (first } \\
\text { team match day) }\end{array}$ & $\begin{array}{l}\text { Intervention } \\
\text { day: } 40 \\
\text { Duration: } \\
3 \mathrm{~h} 2\end{array}$ & $\begin{array}{l}\text { Live a profes- } \\
\text { sional soccer } \\
\text { experience up } \\
\text { close }\end{array}$ & $\begin{array}{l}\text { Entrance to the stadium at the } \\
\text { foot of the field } 1 \mathrm{~h} \text { before the } \\
\text { start of the match } \\
\text { Visualization of the routine } \\
\text { and pre-match warm-up of the } \\
\text { players } \\
\text { Photos and debate about the } \\
\text { role of strengths to become } \\
\text { professional players }\end{array}$ & \multicolumn{2}{|c|}{$\begin{array}{l}\text { Judgment } \\
\text { Perspective } \\
\text { Perseverance } \\
\text { Teamwork } \\
\text { Appreciation of beauty and } \\
\text { excellence }\end{array}$} & $\begin{array}{l}\text {-Basic psycho- } \\
\text { logical needs }\end{array}$ \\
\hline $\begin{array}{l}\text { 19. Sharing experi- } \\
\text { ences: Juanjo (for- } \\
\text { mer club player) }\end{array}$ & $\begin{array}{l}\text { Intervention } \\
\text { day: } 42 \\
\text { Duration: } 1 \mathrm{~h}\end{array}$ & $\begin{array}{l}\text { Know his } \\
\text { life, his } \\
\text { experiences, } \\
\text { strengths and } \\
\text { learning }\end{array}$ & $\begin{array}{l}\text { Guest conference following a } \\
\text { timeline, highlighting moments, } \\
\text { important aspects of his life and } \\
\text { relating it to his strengths } \\
\text { Questions / debate about their } \\
\text { strengths and the relationship } \\
\text { with their experiences }\end{array}$ & \multicolumn{2}{|l|}{$\begin{array}{l}\text { Perspective } \\
\text { Hope } \\
\text { Zest } \\
\text { Perseverance } \\
\text { Humor } \\
\text { Fairness }\end{array}$} & $\begin{array}{l}\text { Sport performance } \\
\text { satisfaction } \\
\text { Well-being }\end{array}$ \\
\hline \multicolumn{7}{|l|}{ Week 7} \\
\hline 20. Personal brand & $\begin{array}{l}\text { Intervention } \\
\text { day: } 44 \\
\text { Duration: } 1 \mathrm{~h}\end{array}$ & $\begin{array}{l}\text { Raise awareness } \\
\text { about the con- } \\
\text { struction of } \\
\text { the personal } \\
\text { brand and the } \\
\text { importance } \\
\text { of what they } \\
\text { publish on } \\
\text { social net- } \\
\text { works }\end{array}$ & $\begin{array}{l}\text { Conference by the Club's com- } \\
\text { munication director, Gabriel } \\
\text { Barros, about personal branding } \\
\text { Questions / debate about the } \\
\text { strengths of the participants and } \\
\text { the relationship with their posts } \\
\text { on social networks }\end{array}$ & $\begin{array}{l}\text { Honesty } \\
\text { Creativity } \\
\text { Prudence } \\
\text { Leadership } \\
\text { Social intel- } \\
\quad \text { ligence }\end{array}$ & \multicolumn{2}{|c|}{ Basic psychological needs } \\
\hline $\begin{array}{l}\text { 21. Sharing } \\
\text { experiences: Edu } \\
\text { Expósito (first } \\
\text { team player) }\end{array}$ & $\begin{array}{l}\text { Intervention } \\
\text { day: } 45 \\
\text { Duration: } 1 \mathrm{~h}\end{array}$ & $\begin{array}{l}\text { Know his } \\
\text { life, his } \\
\text { experiences, } \\
\text { strengths and } \\
\text { learning }\end{array}$ & $\begin{array}{l}\text { Guest conference following a } \\
\text { timeline, highlighting moments, } \\
\text { important aspects of his life and } \\
\text { relating it to his strengths } \\
\text { Questions/debate about their } \\
\text { strengths and the relationship } \\
\text { with their experiences }\end{array}$ & $\begin{array}{l}\text { Perspective } \\
\text { Perseverance } \\
\text { Self-regulation } \\
\text { Humility } \\
\text { Bravery } \\
\text { Prudence }\end{array}$ & \multicolumn{2}{|c|}{$\begin{array}{l}\text { Sport performance satisfac- } \\
\text { tion } \\
\text { Well-being }\end{array}$} \\
\hline
\end{tabular}




\begin{tabular}{|c|c|c|c|c|c|c|}
\hline Name & Intervention day & Objective & Structure & \multicolumn{2}{|c|}{ Character strengths } & Dependent vari- \\
\hline $\begin{array}{l}\text { 22. Forgiveness } \\
\text { in victims of the } \\
\text { FARC guerrilla in } \\
\text { Colombia }\end{array}$ & $\begin{array}{l}\text { Intervention } \\
\text { day: } 46 \\
\text { Duration: } 1 \mathrm{~h}\end{array}$ & $\begin{array}{l}\text { Delve into the } \\
\text { strength of } \\
\text { Forgiveness }\end{array}$ & $\begin{array}{l}\text { Conference by Andrea, a psy- } \\
\text { chologist and researcher from } \\
\text { Colombia who has done a great } \\
\text { field work with direct or indirect } \\
\text { victims of the FARC guerrilla } \\
\text { Questions/debate about the } \\
\text { strength of Forgiveness }\end{array}$ & $\begin{array}{l}\text { Forgiveness } \\
\text { Social intel- } \\
\quad \text { ligence } \\
\text { Fairness } \\
\text { Judgment } \\
\text { Perspective }\end{array}$ & Well-being & \\
\hline $\begin{array}{l}\text { 23. Sharing experi- } \\
\text { ences: Alex Martí } \\
\text { (amateur player) }\end{array}$ & $\begin{array}{l}\text { Intervention } \\
\text { day: } 46 \\
\text { Duration: } 1 \mathrm{~h}\end{array}$ & $\begin{array}{l}\text { Know his } \\
\text { life, his } \\
\text { experiences, } \\
\text { strengths and } \\
\text { learning }\end{array}$ & $\begin{array}{l}\text { Guest conference following a } \\
\text { timeline, highlighting moments, } \\
\text { important aspects of his life and } \\
\text { relating it to his strengths } \\
\text { Questions/debate about their } \\
\text { strengths and the relationship } \\
\text { with their experiences }\end{array}$ & $\begin{array}{l}\text { Perspective } \\
\text { Hope } \\
\text { Zest } \\
\text { Perseverance } \\
\text { Curiosity } \\
\text { Humility } \\
\text { Prudence }\end{array}$ & $\begin{array}{l}\text { Sport perfor } \\
\text { tion } \\
\text { Well-being }\end{array}$ & rmance satisfac- \\
\hline $\begin{array}{l}\text { 24. Film: Informe } \\
\text { Robinson- } \\
\text { Amarelle }\end{array}$ & $\begin{array}{l}\text { Intervention } \\
\text { day: } 46 \\
\text { Duration: } 2 \mathrm{~h}\end{array}$ & $\begin{array}{l}\text { Know his life } \\
\text { and prepare } \\
\text { his visit at } \\
\text { the end of the } \\
\text { program }\end{array}$ & $\begin{array}{l}\text { Movie viewing } \\
\text { Dialogue about observed } \\
\text { strengths }\end{array}$ & $\begin{array}{l}\text { Appreciation } \\
\text { of beauty \& } \\
\text { excellence } \\
\text { Perseverance } \\
\text { Love } \\
\text { Teamwork } \\
\text { Leadership } \\
\text { Zest }\end{array}$ & $\begin{array}{l}\text { Sport perfor } \\
\text { tion } \\
\text { Well-being }\end{array}$ & rmance satisfac- \\
\hline $\begin{array}{l}\text { 25. My little pleas- } \\
\text { ures }\end{array}$ & $\begin{array}{l}\text { Intervention } \\
\text { day: } 47 \\
\text { Duration: } 1 \mathrm{~h}\end{array}$ & $\begin{array}{l}\text { Be aware of the } \\
\text { little things } \\
\text { that bring us } \\
\text { pleasure and } \\
\text { well-being }\end{array}$ & $\begin{array}{l}\text { Travel to Monte de San Pedro } \\
\text { (A Coruña), a privileged place } \\
\text { with great calm and beauty of } \\
\text { the city } \\
\text { Cover a sheet in which they } \\
\text { describe what kinds of things } \\
\text { give them pleasure and how } \\
\text { they feel in those moments } \\
\text { Walk in the mountains in pairs } \\
\text { and share their pleasures } \\
\text { Sharing of the whole group }\end{array}$ & $\begin{array}{l}\text { Creativity } \\
\text { Love } \\
\text { Zest } \\
\text { Appreciation } \\
\text { of beauty \& } \\
\text { excellence } \\
\text { Gratitude } \\
\text { Spirituality }\end{array}$ & Well-being & \\
\hline 26. Why? & $\begin{array}{l}\text { Intervention } \\
\text { day: } 47 \\
\text { Duration: } 1 \mathrm{~h}\end{array}$ & $\begin{array}{l}\text { Be aware of } \\
\text { how our } \\
\text { actions seek } \\
\text { personal hap- } \\
\text { piness }\end{array}$ & $\begin{array}{l}\text { In the Monte de San Pedro (A } \\
\text { Coruña), group reflection on the } \\
\text { question: Why do I get up every } \\
\text { day? From that, the What for? } \\
\text { What are you doing ...? What } \\
\text { do you say ...? What are you } \\
\text { going for ...? Until we conclude } \\
\text { that our actions have the sense } \\
\text { of seeking to try to be happy } \\
\text { and make others happy }\end{array}$ & $\begin{array}{l}\text { Judgment } \\
\text { Perspective } \\
\text { Honesty } \\
\text { Love } \\
\text { Appreciation } \\
\text { of beauty \& } \\
\text { excellence } \\
\text { Spirituality }\end{array}$ & Well-being & \\
\hline $\begin{array}{l}\text { 27. Share stories } \\
\text { of strengths with } \\
\text { peers }\end{array}$ & $\begin{array}{l}\text { Intervention } \\
\text { day: } 47 \\
\text { Duration: } 1 \mathrm{~h}\end{array}$ & $\begin{array}{l}\text { Knowing } \\
\text { classmates' } \\
\text { strengths and } \\
\text { experiences } \\
\text { that reflect } \\
\text { their use }\end{array}$ & $\begin{array}{l}\text { In the Monte de San Pedro (A } \\
\text { Coruña), outdoors and in a quiet } \\
\text { place } \\
\text { Grouped in pairs, and as they } \\
\text { walk, they read stories about } \\
\text { their personal strengths } \\
\text { When they have one read, } \\
\text { they change pairs and pass on } \\
\text { a different one, so everyone } \\
\text { knows a strength and how each } \\
\text { participant uses it }\end{array}$ & $\begin{array}{l}\text { Perspective } \\
\text { Social intel- } \\
\quad \text { ligence } \\
\text { Curiosity } \\
\text { Honesty } \\
\text { Love } \\
\text { Gratitude } \\
\text { Kindness }\end{array}$ & Well-being & \\
\hline
\end{tabular}




\begin{tabular}{|c|c|c|c|c|c|}
\hline Name & $\begin{array}{l}\text { Intervention day } \\
\text { and duration }\end{array}$ & Objective & Structure & Character strengt & $\begin{array}{l}\text { Dependent vari- } \\
\text { able }\end{array}$ \\
\hline 28. Admiration & $\begin{array}{l}\text { Intervention } \\
\text { day: } 47 \\
\text { Duration: } 1 \mathrm{~h}\end{array}$ & $\begin{array}{l}\text { Describe and be } \\
\text { aware of why } \\
\text { we admire } \\
\text { certain people }\end{array}$ & $\begin{array}{l}\text { In the Monte de San Pedro (A } \\
\text { Coruña), delivery of a sheet } \\
\text { in which they must describe } \\
\text { a person they admire and say } \\
\text { the reason for that admiration. } \\
\text { These people should be framed } \\
\text { in the categories: teacher, soccer } \\
\text { player, family and teammate }\end{array}$ & $\begin{array}{l}\text { Appreciation } \\
\text { of beauty \& } \\
\text { excellence } \\
\text { Social intel- } \\
\text { ligence } \\
\text { Judgment } \\
\text { Gratitude } \\
\text { Love }\end{array}$ & Basic psychological needs \\
\hline $\begin{array}{l}\text { 29. Sharing experi- } \\
\text { ences: Ramiro } \\
\text { Amarelle (former } \\
\text { best player in the } \\
\text { World-Beach } \\
\text { soccer) }\end{array}$ & $\begin{array}{l}\text { Intervention } \\
\text { day: } 47 \\
\text { Duration: } 1 \mathrm{~h}\end{array}$ & $\begin{array}{l}\text { Know his life, } \\
\text { his strengths } \\
\text { and profes- } \\
\text { sional experi- } \\
\text { ences }\end{array}$ & $\begin{array}{l}\text { Travel to Monte de San Pedro } \\
\text { (A Coruña), meeting with } \\
\text { Ramiro Amarelle. He shared } \\
\text { his experiences and experiences } \\
\text { as a Deportivo player in base } \\
\text { categories and as a professional } \\
\text { beach soccer player and coach }\end{array}$ & $\begin{array}{l}\text { Perspective } \\
\text { Perseverance } \\
\text { Love } \\
\text { Social intel- } \\
\quad \text { ligence } \\
\text { Teamwork } \\
\text { Leadership } \\
\text { Zest }\end{array}$ & $\begin{array}{l}\text { Sport performance satisfac- } \\
\text { tion } \\
\text { Well-being }\end{array}$ \\
\hline $\begin{array}{l}\text { 30. Appreciation of } \\
\text { beauty and excel- } \\
\text { lence }\end{array}$ & $\begin{array}{l}\text { Intervention } \\
\text { day: } 48 \\
\text { Duration: } 3 \mathrm{~h}\end{array}$ & $\begin{array}{l}\text { Appreciate and } \\
\text { describe what } \\
\text { different situ- } \\
\text { ations evoke } \\
\text { in us }\end{array}$ & $\begin{array}{l}\text { Movie viewing: "Colombia } \\
\text { Magia Salvaje" } \\
\text { Movie viewing: "Informe } \\
\text { Robinson SuperDepor, te quiero } \\
\text { igual" } \\
\text { Dialogue/debate on the mani- } \\
\text { festation of strength "Apprecia- } \\
\text { tion of beauty and excellence" } \\
\text { in these documentaries }\end{array}$ & $\begin{array}{l}\text { Appreciation } \\
\text { of beauty and } \\
\text { excellence }\end{array}$ & Well-being \\
\hline $\begin{array}{l}\text { 31. Conscious use } \\
\text { of strengths }\end{array}$ & $\begin{array}{l}\text { Intervention } \\
\text { day: } 48 \\
\text { Duration: } 1 \mathrm{~h}\end{array}$ & $\begin{array}{l}\text { Know the } \\
\text { strengths we } \\
\text { use and use } \\
\text { them con- } \\
\text { sciously }\end{array}$ & $\begin{array}{l}\text { Record how we use the } \\
\text { strengths during the day to day } \\
\text { (strengths and actions) } \\
\text { Design actions to work each of } \\
\text { the main strengths }\end{array}$ & $\begin{array}{l}\text { Judgment } \\
\text { Perspective } \\
\text { Creativity }\end{array}$ & Self-regulation \\
\hline $\begin{array}{l}\text { 32. Aspects to } \\
\text { improve }\end{array}$ & $\begin{array}{l}\text { Intervention } \\
\text { day: } 48 \\
\text { Duration: } 2 \mathrm{~h}\end{array}$ & $\begin{array}{l}\text { Be aware of the } \\
\text { improvement } \\
\text { aspects that } \\
\text { others see } \\
\text { in us }\end{array}$ & $\begin{array}{l}\text { Sending a questionnaire to } \\
\text { family, colleagues, teachers } \\
\text { and people close to them with } \\
\text { the question: What should I } \\
\text { improve? } \\
\text { Delivery and individual read- } \\
\text { ing of answers to the players } \\
\text { Joint reflection on it. What oth- } \\
\text { ers think of us add up to realize } \\
\text { what we need to improve and to } \\
\text { know ourselves better }\end{array}$ & $\begin{array}{l}\text { Judgment } \\
\text { Social intel- } \\
\quad \text { ligence } \\
\text { Perspective } \\
\text { Honesty } \\
\text { Love } \\
\text { Humility } \\
\text { Self-regulation }\end{array}$ & Basic psychological needs \\
\hline
\end{tabular}




\begin{tabular}{|c|c|c|c|c|c|}
\hline Name & $\begin{array}{l}\text { Intervention day } \\
\text { and duration }\end{array}$ & Objective & Structure & & $\begin{array}{l}\text { Dependent vari- } \\
\text { able }\end{array}$ \\
\hline \multicolumn{6}{|l|}{ Week 8} \\
\hline $\begin{array}{l}\text { 33. Sharing experi- } \\
\text { ences: Ángel } \\
\text { Vales (analyst } \\
\text { of the Spanish } \\
\text { national football } \\
\text { team) }\end{array}$ & $\begin{array}{l}\text { Intervention } \\
\text { day: } 50 \\
\text { Duration: } 2 \mathrm{~h}\end{array}$ & $\begin{array}{l}\text { Know his life, } \\
\text { his strengths } \\
\text { and profes- } \\
\text { sional experi- } \\
\text { ences }\end{array}$ & $\begin{array}{l}\text { Visit to the } \\
\text { UDC Faculty } \\
\text { of Sports Sci- } \\
\text { ences } \\
\text { Meeting with } \\
\text { Ángel Vales } \\
\text { in two groups } \\
\text { of } 5 \text {. He has } \\
\text { told them his } \\
\text { life story, they } \\
\text { asked ques- } \\
\text { tions and he } \\
\text { has left as a } \\
\text { final message } \\
\text { that in life you } \\
\text { have to look } \\
\text { at yourself, } \\
\text { get to know } \\
\text { yourself and } \\
\text { work on your } \\
\text { strengths } \\
\text { and look to } \\
\text { the future by } \\
\text { establishing } \\
\text { goals and } \\
\text { objectives }\end{array}$ & $\begin{array}{l}\text { Perspective } \\
\text { Curiosity } \\
\text { Judgment } \\
\text { Social intelligence } \\
\text { Hope }\end{array}$ & $\begin{array}{l}\text { Sport performance satisfac- } \\
\text { tion } \\
\text { Well-being }\end{array}$ \\
\hline $\begin{array}{l}\text { 34. Sharing experi- } \\
\text { ences: Alex Pais } \\
\text { (former football } \\
\text { player) }\end{array}$ & $\begin{array}{l}\text { Intervention } \\
\text { day: } 50 \\
\text { Duration: } 1 \mathrm{~h}\end{array}$ & $\begin{array}{l}\text { Know his } \\
\text { life, his } \\
\text { experiences, } \\
\text { strengths and } \\
\text { learning }\end{array}$ & $\begin{array}{l}\text { Guest confer- } \\
\text { ence follow- } \\
\text { ing a timeline, } \\
\text { highlighting } \\
\text { moments, } \\
\text { important } \\
\text { aspects of his } \\
\text { life and relat- } \\
\text { ing it to his } \\
\text { strengths } \\
\text { Questions / } \\
\text { debate about } \\
\text { their strengths } \\
\text { and the rela- } \\
\text { tionship with } \\
\text { their experi- } \\
\text { ences }\end{array}$ & $\begin{array}{l}\text { Perspective } \\
\text { Perseverance } \\
\text { Humor } \\
\text { Leadership } \\
\text { Hope } \\
\text { Forgiveness }\end{array}$ & $\begin{array}{l}\text { Sport performance satisfac- } \\
\text { tion } \\
\text { Well-being }\end{array}$ \\
\hline
\end{tabular}




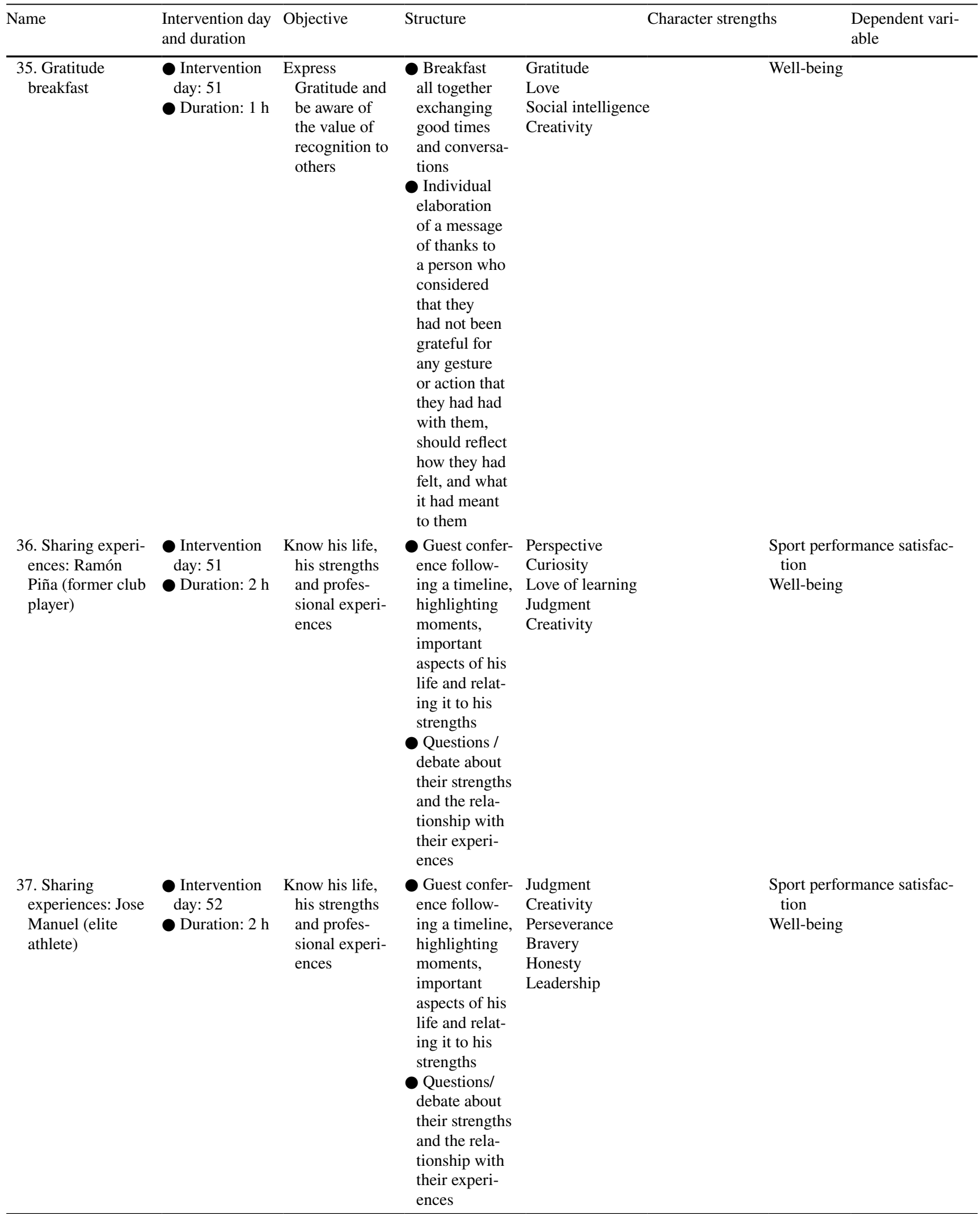




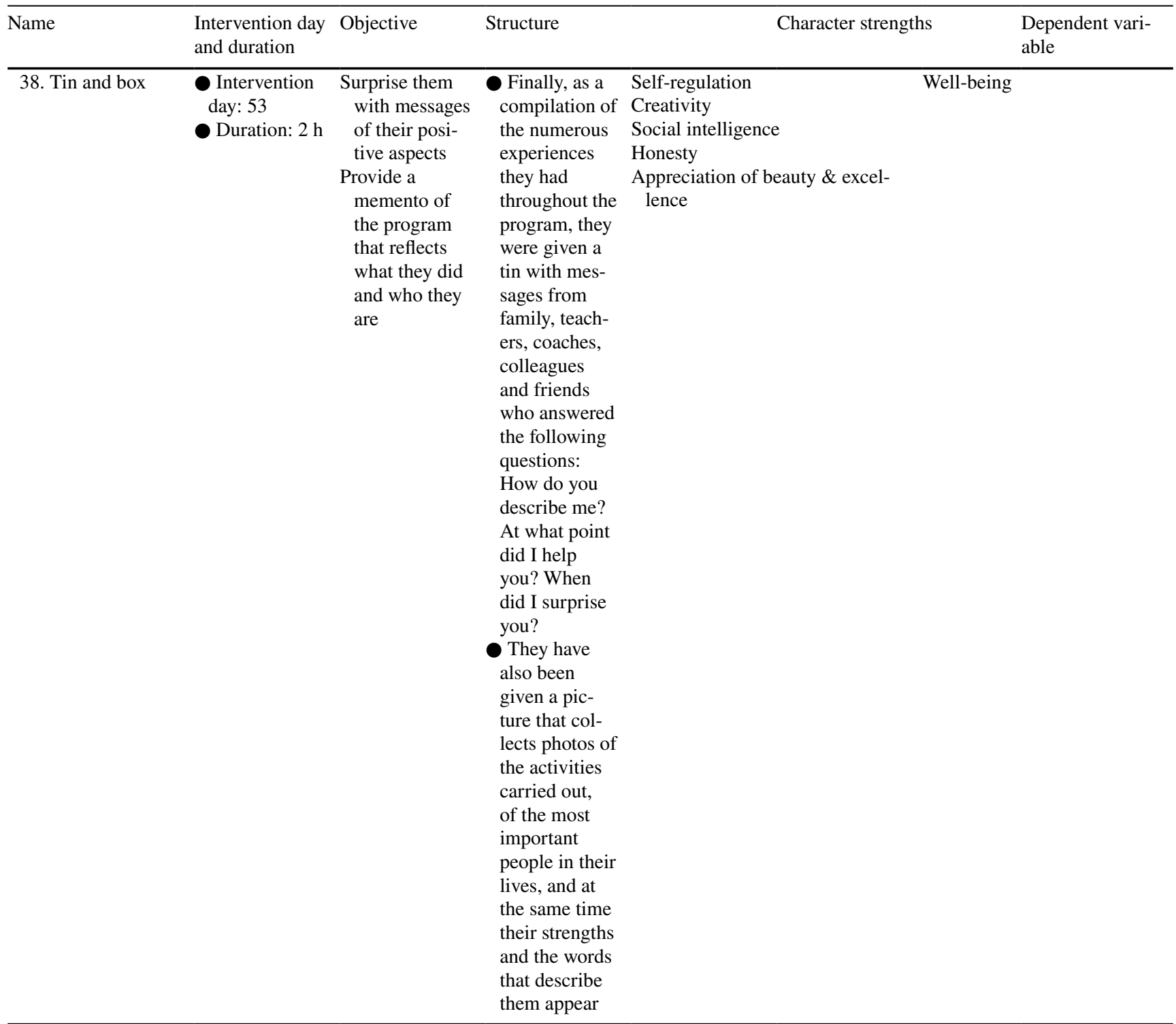

Acknowledgements The authors want to thank the collaboration of the Real Club Deportivo de La Coruña S.A.D. and those who participated in the program's activities (former players, executives, coaches, etc.). Furthermore, we are especially grateful for the collaboration of Belén Varela and Ramiro Amarelle.

Funding Open Access funding provided thanks to the Universidade da Coruña/CRUE-CSIC agreement with Springer Nature.

\section{Declarations}

Conflict of interest The authors declare that there is no conflict of interest regarding the publication of this article.

Human and animal rights The treatment of human rights in the study followed the recommendations of the Research Ethics Commission of the University of A Coruña and the Declaration of Helsinki (1964). This article does not contain any animal studies conducted by any of the authors.
Ethical approval The study followed the recommendations of the Ethics Commission of Research of the University of A Coruña and the Declaration of Helsinki (1964).

Informed consent Informed consent was obtained for each participant.

Open Access This article is licensed under a Creative Commons Attribution 4.0 International License, which permits use, sharing, adaptation, distribution and reproduction in any medium or format, as long as you give appropriate credit to the original author(s) and the source, provide a link to the Creative Commons licence, and indicate if changes were made. The images or other third party material in this article are included in the article's Creative Commons licence, unless indicated otherwise in a credit line to the material. If material is not included in the article's Creative Commons licence and your intended use is not permitted by statutory regulation or exceeds the permitted use, you will need to obtain permission directly from the copyright holder. To view a copy of this licence, visit http://creativecommons.org/licenses/by/4.0/. 


\section{References}

1. Littlewood M, Mullen C, Richardson D (2011) Football labour migration: an examination of the player recruitment strategies of the 'big five'European football leagues 2004-5 to 2008-9. Soccer Soc 12(6):788-805. https://doi.org/10.1080/14660970.2011. 609680

2. Güllich A (2014) Selection, de-selection and progression in German football talent promotion. Eur J Sport Sci 14(6):530-537. https://doi.org/10.1080/17461391.2013.858371

3. Kassis M, Schmidt SL, Schreyer D, Torgler B (2017) Who gets promoted? Personality factors leading to promotion in highly structured work environments: evidence from a German professional football club. Appl Econ Lett 24(17):1222-1227. https:// doi.org/10.1080/13504851.2016.1267841

4. Anderson G, Miller RM (2011) The academy system in english professional football: business value or "following the herd"? Research paper series No 2011/43. University of Liverpool Management School

5. Bisquerra-Alzina R, Hernández-Paniello S (2017) Psicología positiva, educación emocional y el programa aulas felices. Papeles Del Psicól 37(1):58-65. https://doi.org/10.23923/pap.psicol2017.2822

6. Cruz J, Garcia-Mas A, Stambulova N, Lucidi F, Márquez S, Reyes S, Serpa S, Jaenes JC (2017) Psytool design and theoretical background. Communication at the XIV ISSP World Congress, Sevilla (Spain).

7. García-Mas A, Rosado A, Serpa S, Marcolino P, Villalonga C (2018) Content analysis of the agents of change" disposition to change" after attending the psytool program. Rev Psicol Deporte 27(3):31-36

8. Duda JL, Quested E, Haug E, Samdal O, Wold B, Balaguer I, Hall $\mathrm{H}$ (2013) Promoting adolescent health through an intervention aimed at improving the quality of their participation in Physical Activity (PAPA): background to the project and main trial protocol. Internat J Sport Exe Psychol 11(4):319-327. https://doi.org/ 10.1080/1612197x.2013.839413

9. Côté J, Hancock DJ (2016) Evidence-based policies for youth sport programmes. Internat J Sport Pol Polit 8(1):51-65. https:// doi.org/10.1080/19406940.2014.919338

10. Koh KT, Ong SW, Camiré M (2016) Implementation of a values training program in physical education and sport: perspectives from teachers, coaches, students, and athletes. Phys Educ Sport Pedagog 21(3):295-312. https://doi.org/10.1080/17408989.2014. 990369

11. Holt NL, Neely KC (2011) Positive youth development through sport: a review. Rev Iberoam Psicol Ejercicio y el Dep 6(2):229-316

12. Larson RW (2000) Toward a psychology of positive youth development. Am Psychol 55(1):170-183. https://doi.org/10.1037// 0003-066x.55.1.170

13. Donaldson SI, Csikszentmihalyi M, Nakamura J (2011) Applied Positive psychology: Improving everyday life, health, schools, work, and society. Routledge Academic

14. Salanova M, Schaufeli WB, Xanthopoulou D, Bakker AB (2010) The gain spiral of resources and work engagement: sustaining a positive worklife. In: Bakker AB, Leiter MP (eds) Work engagement: a handbook of essential theory and research. Psychology Press, pp 118-131

15. Csikszentmihalyi M (2014) Flow and the foundations of positive psychology. Springer

16. Bakker AB, Hetland J, Olsen OK, Espevik R (2019) Daily strengths use and employee well-being: the moderating role of personality. J Occup Organ Psychol 92(1):144-168. https://doi. org/10.1111/joop. 12243
17. Ng V, Cao M, Marsh HW, Tay L, Seligman ME (2017) The factor structure of the values in action inventory of strengths (VIA-IS): an item-level exploratory structural equation modeling (ESEM) bifactor analysis. Psychol Assess 29(8):1053. https://doi.org/10. 1037/pas0000396

18. Azañedo CM, Fernández-Abascal EG, Barraca J (2014) Character strengths in Spain: validation of the values in action inventory of strengths (VIA-IS) in a Spanish sample. Clín Salud 25(2):123130. https://doi.org/10.1016/j.clysa.2014.06.002

19. Littman-Ovadia H, Freidlin P (2019) Positive psychopathology and positive functioning: OCD, flourishing and satisfaction with life through the lens of character strength underuse, overuse and optimal use. Appl Res Qual Life. https://doi.org/10.1007/ s11482-018-9701-5

20. Brady A, Grenville-Cleave B (2017) Positive psychology in sport and physical activity. Routledge

21. Ludlam KE, Butt J, Bawden M, Lindsay P, Maynard IW (2016) A strengths-based consultancy approach in elite sport: exploring super-strengths. J Appl Sport Psychol 28(2):216-233. https://doi. org/10.1080/10413200.2015.1105881

22. Shin J, Jang H, Hyun M (2015) Stress coping and emotional regulation mediate between character strengths and adjustment. Korean J Stress Res 23(3):109-118. https://doi.org/10.17547/kjsr. 2015.23.3.109

23. Young KC, Kashdan TB, Macatee R (2015) Strength balance and implicit strength measurement: new considerations for research on strengths of character. J Posit Psychol 10(1):17-24. https://doi. org/10.1080/17439760.2014.920406

24. Harzer C, Ruch W (2015) The relationships of character strengths with coping, work-related stress, and job satisfaction. Front Psychol. https://doi.org/10.3389/fpsyg.2015.00165

25. Pang D, Ruch W (2019) Fusing character strengths and mindfulness interventions: benefits for job satisfaction and performance. J Occup Health Psychol 24(1):150-162. https://doi.org/10.1037/ ocp0000144

26. Coghlan A, Filo K (2016) Bringing personal character strengths into the production of the leisure experience. Leis Sci 38(2):100 117. https://doi.org/10.1080/01490400.2015.1087355

27. Gander F, Hofmann J, Proyer RT, Ruch W (2019) Character strengths - stability, change, and relationships with wellbeing changes. Appl Res Qual Life. https://doi.org/10.1007/ s11482-018-9690-4

28. Pang D, Ruch W (2019) The mutual support model of mindfulness and character strengths. Mindfulness 10(8):1545-1559. https:// doi.org/10.1007/s12671-019-01103-z

29. Littman-Ovadia H, Niemiec RM (2016) Character strengths and mindfulness as core pathways to meaning in life. In Clinical perspectives on meaning. Springer, pp 383-405

30. De Francisco C, Parra FJ, Arce C, Vílchez MDP (2018) Preliminary empirical validation of the "basic needs satisfaction in sport scale" with a sample of Spanish athletes. Front Psychol 9:1057. https://doi.org/10.3389/fpsyg.2018.01057

31. Linley PA, Nielsen KM, Gillett R, Biswas-Diener R (2010) Using signature strengths in pursuit of goals: effects on goal progress, need satisfaction, and well-being, and implications for coaching psychologists. Int Coach Psychol Rev 5:6-15

32. Ryan RM, Deci EL (2017) Self-determination theory: basic psychological needs in motivation, development, and wellness. Guilford Press

33. Niemiec RM (2017) Character strenghts interventions: a field guide for practitioners. Hogrefe Publishing

34. Peterson C, Seligman ME (2004) Character strengths and virtues: a handbook and classification. Oxford University Press. https:// doi.org/10.5860/choice.42-0624

35. Ruch W, Gander F, Wagner L, Giuliani F (2019) The structure of character: on the relationships between character strengths and 
virtues. J Posit Psychol. https://doi.org/10.1080/17439760.2019. 1689418

36. Brdar I, Kashdan TB (2010) Character strengths and well-being in Croatia: an empirical investigation of structure and correlates. J Res Pers 44(1):151-154. https://doi.org/10.1016/j.jrp.2009.12. 001

37. Toner E, Haslam N, Robinson J, Williams P (2012) Character strengths and wellbeing in adolescence: structure and correlates of the values in action inventory of strengths for children. Personal Individ Differ 52(5):637-642. https://doi.org/10.1016/j.paid.2011. 12.014

38. McGrath RE (2014) Character strengths in 75 nations: an update. J Posit Psychol 10(1):41-52. https://doi.org/10.1080/17439760. 2014.888580

39. Tomé-Lourido D (2018) Evaluación de habilidades psicológicas en deportistas, y su relación con la ansiedad y el procesamiento atencional. (Unpublished doctoral dissertation). University of Santiago de Compostela. https://www.educacion.gob.es/teseo/ mostrarRef.do?ref=1710402

40. Fordyce MW (1983) A program to increase happiness: further studies. J Couns Psychol 30(4):483-498. https://doi.org/10.1037/ 0022-0167.30.4.483

41. University of Pennsylvania (2019) Fordyce emotions questionnaire. https://www.authentichappiness.sas.upenn.edu/es/testcenter

42. Díaz D, Rodríguez-Carvajal R, Blanco A, Moreno-Jiménez B, Gallardo I, Valle C, Dierendonck DV (2006) Adaptación española de las escalas de bienestar psicológico de Ryff. Psicothema 18(3):572-577

43. Tomé-Lourido D, Arce C, Ponte D (2018) Adaptation of the test of performance strategies competition subscale to Spanish. Psicothema 30(1):123-129. https://doi.org/10.7334/psicothema2017. 124
44. León OG, Montero I (2015) Métodos de investigación en psicología y educación. McGraw-Hill

45. Luthans F, Avolio BJ, Avey JB, Norman SM (2007) Positive psychological capital: measurement and relationship with performance and satisfaction. Pers Psychol 60(3):541-572. https:// doi.org/10.1111/j.1744-6570.2007.00083.x

46. Ortega-Maldonado A (2018) It is time to act! Empirical findings on how to enhance psychological well-being and performance through positive interventions. (Unpublished doctoral dissertation). Universitat Jaume I. https://www.educacion.gob.es/teseo/ mostrarRef.do?ref $=1675614$

47. Peterson C, Ruch W, Beermann U, Park N, Seligman ME (2007) Strengths of character, orientations to happiness, and life satisfaction. J Posit Psychol 2(3):149-156. https://doi.org/10.1080/17439 760701228938

48. Schutte NS, Malouff JM (2018) The impact of signature character strengths interventions: a meta-analysis. J Happiness Stud 20(4):1179-1196. https://doi.org/10.1007/s10902-018-9990-2

49. Park N, Peterson C, Seligman ME (2004) Strengths of character and well-being. J Soc Clin Psychol 23(5):603-619. https://doi.org/ 10.1521/jscp.23.5.603.50748

50. Wagner L, Gander F, Proyer RT, Ruch W (2019) Character strengths and PERMA: investigating the relationships of character strengths with a multidimensional framework of well-being. Appl Res Qual Life. https://doi.org/10.1007/s11482-018-9695-Z

51. Hausler M, Strecker C, Huber A, Brenner M, Höge T, Höfer S (2017) Distinguishing relational aspects of character strengths with subjective and psychological well-being. Front Psychol. https://doi.org/10.3389/fpsyg.2017.01159

Publisher's Note Springer Nature remains neutral with regard to jurisdictional claims in published maps and institutional affiliations. 